\title{
The intelligentsia in the constitution of civil societies and post-communist regimes in Hungary and Poland ${ }^{1}$
}

\author{
MICHAEL D. KENNEDY \\ Department of Sociology, University of Michigan
}

The most prominent actor in the 1989 transformation of Eastern Europe has been the intelligentsia, a class whose basis for power is its control over a special form of teleological knowledge, and a culturally constituted group whose claim to authority is its historic role as leaders of East European nations. ${ }^{2}$ In the wake of revolution they have in most places replaced the communist party and won political authority. In this article I explain the process through which the intelligentsia has apparently come to power, the character of its authority made in struggle, and what alternative futures post-communism might have for the prospects of the intelligentsia.

The commonality of the intelligentsia's authority suggests a powerful and common structure at work in communism's fall. I argue that there is indeed such a deep structure of antagonism between the intelligentsia and the Soviet-type system on the one hand, and considerable determinism in the initial shape of post-communism on the other. But to lose sight of the contingencies shaping the transition itself would suggest a determinism in process that is analytically, it not also empirically, indefensible.

The intelligentsia's ascension depended on the possibilities of a negotiated settlement between it and reformers in the communist party, which itself depended on the at least implicit acceptance by the popular classes of the intelligentsia's representation. The intelligentsia won this authority by becoming spokespersons for a new universalism, civil society. But this civil society contained several possible meanings, and excluded many significant questions from its conceptualization. The future of post-communist systems depends on how civil society's contradictions and exclusions are worked out as conflicts within and about the intelligentsia and its efforts to legislate a new society rage. 
Because this story continues to unfold in ways too difficult to anticipate with any confidence, I focus this essay on the period leading up to the formation of post-communist regimes. I discuss how the Polish intelligentsia's immersion in civil society contributed to the emergence of Solidarity in 1980-81 as a cross-class movement identifying with pluralism, equality, and self-management. I then turn to the difference between Poland and Hungary, emphasizing not only social conditions but also the different legacies of opposition to the Soviet-type system in these two societies. I subsequently discuss how the Hungarian intelligentsia created its own civil society, and illustrate that with reference to two forms of self-organization based on the intelligentsia itself. Next I compare both countries' transition to post-communism, emphasizing above all the negotiations that occurred in them between communist reformers and the intelligentsia as representatives of civil society. In both countries, I discuss the appearance of an intelligentsia that has come to power, but argue rather that this intelligentsia has used its power to elevate the authority of markets, and thereby legislate a new system that tranforms and undermines the very basis for its class power. Before I turn to the question of the intelligentsia and these specific comparisons, I discuss briefly the place of Poland and Hungary in East European transition in order to suggest why they deserve analytical priority.

\section{Eastern Europe and the intelligentsia in the Soviet-type system}

Perestroika was of course the necessary condition for systematic transformation in Eastern Europe, but it was itself moved by the experiences of Poland and Hungary. Hungary was observed closely by Soviet authorities as a model for communism's economic transformation. Poland was also being watched, if with a less admiring eye. General Jaruzelski's failure to restore economic and political order without Solidarity meant that the Soviets were facing few options in Poland at the end of the 1980 s other than invasion or emancipation. The relative costs of the invasion and withdrawal of troops from Afghanistan probably suggested to many Soviet leaders that emancipation would cost the U.S.S.R. far less than occupation. Poland and Hungary are thus important because these places more than the others are the ones that moved the tranformation of all Soviet-type societies.

No one anticipated how quickly the transformation of Eastern Europe would take place. Each place deserves its own analysis in this year of 
revolution, but Poland and Hungary might deserve analytical priority for several reasons. First, the dynamics that have established their postcommunist regimes are the most internally derived. ${ }^{3}$ External intervention and imitations has been least important for the Polish and Hungarian transitions, while their transitions were critical for moving change in East Germany, Czechoslovakia, Bulgaria, Romania, and much later, Albania. Second, these societies initiated the transitions and were the pathbreakers for post-communist tranformation. They tested the limits of change in Soviet foreign policy, with Poland's first partially free elections, and with Hungary's open border with Austria. Finally, they imply two alternatives in post-communist transition, with the Polish tranformation having been based on a cross-class alliance in civil society against the authorities, and the Hungarian transition depending more on a negotiated alliance between Party reformers and opposition intellectuals. They offer the opportunity for neat comparison, therefore, especially so as to explain why the intelligentsia becomes so prominent in case of either transition motivated first by negotiation at the top or pressure from the bottom, suggesting a measure of determinism the suggestion of transition's contingency denies. But before I turn to this Polish-Hungarian comparison, I discuss briefly the general situation of the intelligentsia in the communist system in order to establish the commonality that makes meaningful the contrast of contexts.

In the absence of a strong bourgeoisie and given the centrality of nationalism, East European intellectuals were moved to prominence in practical politics before World War II. ${ }^{4}$ In several senses, the Soviettype system continued that practice. The Party pretended to be the collective intellectual, realizing for society and the universal class their interests. It also claimed managerial expertise, expressed through centralized planning and organizational hegemony. ${ }^{5}$ The intelligentsia and the Party both shared an interest in elevating their capacity for teleological knowledge to a superior position in the legitimation of surplus's distribution. ${ }^{6}$ But autonomous intellectuals were an anachronism in such a system, especially when that system was forced on a resistant culture and intellectuals struggled to retain their distinction.

If the distinction of autonomous intellectuals resides in their capacity to redefine their distinction, ${ }^{7}$ the Soviet-type system was not their class project. Even while the Soviet-type system elevated the intelligentsia by eliminating class rivals and promoting a knowledge-based class order, it also sought to take away from intellectuals their distinction in the name of a supra-individual rationality. Where in other social orders, 
intellectuals were privileged not only by rank but also by a qualitatively separate status based on the distinction they cultivated and elaborated, in the new order they were placed on top of a hierarchy that denied their qualitative difference.

Most obviously state censorship denies intellectuals the capacity to define their product. Imposed styles, as socialist realism, aim to reduce intellectual distinction, but even in more subtle ways, the Soviet-type system oppresses this distinction. The idea that intellectuals, as others, should serve common interest means that intellectuals are denied the privilege of defining their master, a condition especially noxious when but for state power other patrons could be sought. Collectivism, even one based on some order favorable to the material interests of intellectuals, works to deny the individualistic foundation that makes the intellectual as actor distinctive. As Bahro argued, ${ }^{8}$ the Soviet-type system produced "surplus consciousness," where bureaucratic domination suppressed the creative capacity of individuals, especially of intellectuals.

This incompatibility between intellectual and Soviet-type system operates mainly at the ideological level, however. In fact, in the very attempt to control and limit the intellectual's distinction, the system elevated the intellectual and her search for "truth." By contrast, the market, with its tolerance and embrace of the individual, works to undermine the creative project by submitting it to the market and its tyranny, while nevertheless creating an image of intellectual freedom. ${ }^{9}$ The vision of Soviet-type totalitarianism clearly identified the autonomous intellectual as opponent, thereby moving such an intellectual to prominence in opposition and to a natural solidarity with a broader resistance to the existing regime.

\section{The intelligentsia in the tranformation of the Soviet-type system}

Revisionism offered one means by which communist principles could have been transformed to make intellectuality and the Soviet-type system compatible, but by 1968 revisionism was defeated as an East European project. ${ }^{10}$ Intellectuals remaining within the system were left without an independent tranformative identity aside from their domestic national one. As such, many of those formerly engaged in the transformation of the Marxian project were led to search for what their own national tradition meant, and to reconstruct it. This became especially 
important as they sought to distinguish their nationalism from those who from communism's imposition rested on traditional nationalism to define their opposition. This nationalism had been, after all, the natural vehicle for the intelligentsia's opposition to the form of communism characterizing the Soviet-type system in Eastern Europe. ${ }^{11}$ Communism there was an extension of Soviet power, on the one hand, and nationalism typically had no inborn animosity to the intellectual, on the other.

Traditional themes in nationalist politics and identity formation generally rely on some kind of reaction rather than a positive project of identity formation, however. That also means that nationalist projects will acquire different expressions in each East European setting. In Poland, where Polish ethnicity is claimed by over 95 percent of the population, nationalism was most obviously expressed in a continuation of the struggles from before World War I with the demand for a truly independent state, this time free of Soviet/Russian/Communist domination. ${ }^{12}$ Other nationalisms also focused on this state project, but generally not in the same way as the Poles whose numerical preponderance and geographical spread in Eastern Europe encouraged their vision of another great state, as they had centuries earlier. The struggle for statehood by Croatia and Slovenia are not on the same scale, even if they do express something similar: that if only our nation could have its own state, it could be great, or even normal, again.

Like Poland, Hungary also has a stong historical memory of its great power status, but unlike Poland, its nationalism does not focus on state power. Former Hungarian dissident Mihály Vajda describes the difference: "The independence of the great Polish nation is very important to the Poles. It is absolutely unimportant to the Hungarians. National consciousness does exist in a lot of respects, but a big and independent Hungarian country is not an issue for Hungarians at all." ${ }^{13}$ This Hungarian difference seems to be a consequence of the twentieth century's lessons.

The costs of the Soviet invasion of 1956 crushed the appeal of a nationalist discourse that focused on the militant struggle for an independent Hungarian state. But even earlier, expansionist and statist nationalism was undermined by the results of World War I, when Hungarian territory was radically circumscribed, leaving many Hungarians in other states: in Slovakia, in Yugoslavia's Vojvodina, and especially in Romania. The results of World War II only reinforced that sense of 
national dismemberment. With the distribution of the means of violence as they are, redrawn state borders and great power status are less feasible as a focus for Hungarian nationalism's main aspiration. Concern over those Hungarian minorities in border states does, however, provide nationalism its main theme.

These nationalisms seem mostly defensive, or at least non-offensive, as they are directed primarily against nationalities with greater resources. Many of the other East European nationalisms have as a dominant theme some kind of threat to minority populations, however. The Serbs express their nationalism in the struggle to retain control over their historic homeland in Kosovo, with the consequent threat against Albanians. The Romanians and Bulgarians express their nationalism with the repression of the cultural rights of their Hungarian and Turkish minorities in particular. German nationalism, given its twentieth-century experience, tends to be far more cautious. Instead of longing for the reacquistion of now Polish lands, it is much safer to insist upon the "naturally" united Germany, even while the rest of Eastern Europe most fears this national identity.

Nevertheless, all of these East European nationalisms contain the potential for combining the defensive with the offensive. Although there has been an effort within East European civil societies to oppose intolerance and especially anti-Semitism, its potential continues to exist and only conscious struggle against it seems to work against its revival. This conflict, between an chauvinistic nationalism and a universalistic one is, in fact, one of the principal struggles defining the post-communist epoch, and was one of the tensions the struggle for civil society could cover over.

In the communist system, the struggle for national independence and state power could easily define the first kind of opposition. But such a nationalism also could be translated into the suppression of others' rights, much as its promoters struggled to realize their own. A new "universalistic" kind of nationalism, based on the development of civil society, was developed under communism in opposition to this older form. Rather than assert the rights of one's own nationality over those of others, this new kind of nationalism had two key themes: European identity and national equality, with each reinforcing the other.

National equality not only meant that the Soviet empire had no right to determine the national futures of the various East European societies, 
namely that states are of equal stature, but also that state-forming nationalities had no right to assert their needs over the needs of other nationalities in their own states. János Kis, for instance, asserted that for Hungarians to demand better treatment for their minorities abroad, they must also assure the rights of their own minorities, most notably Gypsies. $^{14}$

The European identity was also part of this liberal redefinition of national consciousness. To emphasize a nation's European heritage was to do two things at once: first, to emphasize the distinction of this people from the "Western Asian" Russians, for whom the Soviet-type of communism might seem natural or appropriate. ${ }^{15}$ Second, it was to give the nation a broader identity that would allow it to avoid the glorification of its own singular identity, and rather escalate the principles of a liberal and civil society to an element of the national heritage. Indeed, rather than cultural peculiarity, this version of nationalist consciousness emphasized the European, albeit "universal," virtues of human rights and civil society.

Former Polish dissident and present parliamentarian Adam Michnik, ${ }^{16}$ who certainly would number among proponents of the latter vision, named Sacharov in the U.S.S.R., Kis in Hungary, and Havel in Czechoslovakia also as representatives of this tradition. These men were promoting this vision long before they were vying for national political authority. But when they were dissidents, their reconstructions of national identity were mostly important for those intellectuals normally engaged in the project of cultural debate: political dissidents and humanistic intellectuals. The mass intelligentsia had only a limited identification with this East European legacy. Indeed, the Soviet-type system intentionally recreated the region's intelligentsia so as to move such questions outside their professional competence and personal province.

In higher education, the system moved away from the broadly educated to the narrowly trained, reducing the numbers of humanists and lawyers trained and increasing dramatically the number of engineers. The system tried to generate an intelligentsia that shared no cultural identity, ${ }^{17}$ and rather was a stratum of highly educated, narrowly trained specialists, whose professionalism would be promoted so long as they avoided the kinds of questions that had preoccupied the East European intelligentsia in the past, namely national identity and social justice. $^{18}$ 
As such, the cultural struggle to promote nationalism, or to transform national identity into one of a liberal civil society, also was a struggle to transform the Soviet-type system's increasingly "professional" intelligentsia into one more like its traditional East European form. In a sense, one could think of this as a struggle of the East European life world against the Soviet-type system. ${ }^{19}$ But in fact, this cultural struggle also could draw upon the system's own internal contradictions when it came to professionalism. An anti-systemic identity born in the subordination of professionalism to illegitimate political standards and incompetent managerial practices ${ }^{20}$ served to make the civil society argument appealing even to the apolitical but professionally minded. To rid themselves of the incompetent politically appointed bureaucrats would allow for professional qualifications to rule the day.

The only problem, of course, was that these same political appointees were the ones who decided professional careers. So, even if sympathetic, the idea of civil society emerging from within East European communism had to await social struggles that would make this framework for opposition sensible for the mass of professionals to support actively. Given this dependence on social struggles, the construction of civil society as Eastern Europe's emancipatory alternative took different courses in different societies. Thus, it is best now to turn to specifics, and begin with Poland to see how a civil society based on a national cross-class alliance was constructed.

\section{The intelligentsia's immersion in Polish civil society}

After the debacle of 1968, in which intellectuals and students were isolated in protest and submitted to anti-intellectual and anti-semitic exhortations, imprisonment and exile, workers became Poland's central tranformative actors. In late 1970 and early 1971, workers took to the streets in mass demonstrations, but this time they were isolated, as intellectuals remained quiescent, being both exhausted and resentful of their treatment by the working class two and one-half years earlier. But the workers' isolation did not prove so disastrous as the intellectuals', as they were able to turn out the old Party leadership around Gomutka, and replace him with Edward Gierek, a technocratic Party leader from Silesia. When Gierek would ask workers for help in constructing a new Poland, in the beginning workers would respond enthusiastically. 
Gierek's Poland was based on a new model of growing consumerism, greater professionalism, and technocratic ideology. Some intellectuals were thus drawn into the Gierek program with promises that their expertise would be employed in the construction of the new order. Although the communist regime contined to be "alien" to the Polish nation, the demands of ideology receded. Few took it seriously, and loyalty to the regime came to consist in ritualistic practices and an absence of oppositional activity. Much as in Hungary, where Party leader János Kádár had said a decade earlier that those who are not against us are with us, in Poland the politics of intellectuals came to resemble more and more the tradition of "organic work" (praca $u$ postaw), where professionalism could take the place of overt political activity. The obviousness of this political response began to disappear in the mid-1970s, however.

In 1975, Gierek wanted to demonstrate his loyalty to the Soviet Union by introducing changes to the Constitution. He sought to add two particularly offensive phrases, one concerning the leading role of Poland's communist party in all spheres of social life (rather than the leading role of the working class) and the other about unshakeable and fraternal bonds between the U.S.S.R. and Poland. This generated not only a considerable intellectual backlash but also a sharp reaction by the Catholic Church hierarchy in the persons of Primate Stefan Wyszyński and Cardinal Karol Wojtyta. With this development, the Catholic Church began to move away from its cautious relationship to the authorities, and to support the political opposition more and more. ${ }^{21}$ By 1977, one of the leaders of the 1968 student demonstrations, Adam Michnik, began to argue that the Church and those in the tradition of the anti-clerical left have reason for dialogue and common opposition to the Polish authorities. Although his Kościót, Dialog, Lewica (The Church, Dialogue, the Left) ${ }^{22}$ produced considerable interest within Poland, a shorter essay was more consequential. "The New Evolutionism" was one of the first programmatic statements to suggest the course Solidarity followed later.

Michnik argued against the prevailing political legacies of $1956 .{ }^{23}$ Both revisionism and neopositivism ${ }^{24}$ depended on the activities of elites, not on mass public pressure. The dependence of both strategies on initiation from above thus led them to choose the wrong sides in periods of open conflict. The only strategy that might consistently lead to the right choice is one based on "an unceasing struggle for reform and evolution that seeks an expansion of civil liberties and human rights." 25 
Michnik concludes, "In searching for truth, or, to quote Leszek Kołakowski, 'by living in dignity', opposition intellectuals are striving not so much for a better tomorrow as for a better today. Every act of defiance helps us to build the framework of democratic socialism, which should not be merely or primarily a legal institutional structure but a real dayto-day community of free people." ${ }^{26}$

Michnik's essay helped to lay an intellectual foundation for the Solidarity movement in Poland. It constructed a program that was unambiguously on the side of society against the authorities, and without possibility for compromise with them. It therefore represented a form of national identification, while not demanding that the rights of Polish nationhood be elevated over other peoples. It could not easily be attacked from any ideological position, especially since most political groups at least pay lip service to the idea of human rights. And it promised a new universality, one that could eclipse the claims of Marxism. Here, human rights were in everyone's interests, serving equally well workers, peasants, and intellectuals. But perhaps even more significant than the essay, Michnik and other intellectuals formed a group that demonstrated in practice what the essay suggested.

The Committee in Defense of Workers (Komitet Obrony Robotników or KOR) was formed to help those workers and their families victimized by the authorities after the 1976 strikes and demonstrations. These were above all traditional creative intellectuals ${ }^{27}$ who put their capacities at the service of workers. Not only did they try to raise money to help them, but also tried to facilitate directly the self-organization of society by advocating independent trade unions through the Charter of Workers' Rights. ${ }^{28}$ The Solidarity movement, although not a product of these intellectuals' efforts alone, ${ }^{29}$ was certainly influenced by this new image of opposition: civil society against the state. ${ }^{30}$

This civil society was tied closely, although not entirely, to the Catholic Church. Lay Catholic intellectuals, organized in Clubs of Catholic Intellectuals, were frequent advisors and contributors to the movement. Church premises could be used as meeting places. Religious clerical networks connecting pulpits, and therefore congregations, could provide a means for communicating a coherent message to a significant proportion of Poles. The elevation of Kraków Archbishop Karol Wojtyta to Pope also gave Poles a new charismatic figure with whom to identify. His visit to Poland in 1979 was organized by civil society itself, without state assistance, thereby providing an important lesson in self- 
organization. Perhaps equally important, the Pope's language provided to Polish citizens a new vocabulary for expressing their resistance to the regime.

The traditional language of liberation had been appropriated by the authorities. Words like "socialism," "self-management," and "class struggle" compromised those who uttered them. ${ }^{31}$ The Pope provided instead a language that expressed emancipation in terms of human dignity, truth, and solidarity. These were words that could be used without compromise to express the common interests of civil society against the authorities. Pope John Paul II's invectives against the language of class struggle in liberation theology reflect this background of struggle against Poland's communist authorities. This opposition to Marxist language also had an important function in Polish politics, as class antagonisms were one of the foundations for the reproduction of the communist order.

In Soviet-type systems as elsewhere, workers typically resent intellectuals' arrogance and privilege, while intellectuals often distrust workers' fundamentalist or populist politics. The communist authorities have exploited this distrust in their effort to quell any kind of unified opposition to them..$^{32}$ The idea of civil society, and the terminology of dignity and solidarity allowed an escape from this principal barrier to an organized civil society.

The civil society project was also successful in organizing an opposition to the Soviet-type system because it contained no substantive politics. It said nothing about the distribution of wealth, ownership of the means of production, or division of labor. Strategically, it offered a means for the construction of cross-class alliances, as intellectuals could offer their support in the defense of the civil liberties and human rights of those with weaker ties to the media and poorer skills at publicizing their oppression. In return, the collective strength of self-organized workers could build public pressure on the authorities to respect the rights and liberties the intellectuals moved to the public sphere. On this foundation, Solidarity could be formed.

\section{The character of Polish Solidarity}

Solidarity was an alliance of all classes in Polish civil society against the state. It was, therefore, more than an alliance of disgruntled workers 
and dissident historians and journalists. The majority of the broader class of intelligentsia also belonged to the union. Although workers were far and away the numerical majority of this union, the highly educated were overrepresented in the leadership of the movement. And even where workers were in the leadership, as Lech Walesa and Zbigniew Bujak, they depended heavily on intellectual advisors like Michnik, Jacek Kuron, Tadeusz Mazowiecki, and Bronislaw Geremek. ${ }^{33}$ This was, of course, a workers' movement based on the experiences of the working class in Gdansk, Szczecin, Silesia, and other industrial centers, ${ }^{34}$ but it also was heavily influenced by the dissident intellectuals who promoted the idea of civil society's struggle against the state, and by the broader intelligentsia that promoted professionalism over politics.

The two principal classes of urban Solidarity in 1980-81 had different emphasis in their politics. Workers were above all interested in a kind of radical trade unionism, from a militant defense of local issues to a kind of self-managing economic reform based on workers' councils. All sectors of society had to be interested in such a trade unionism in the beginning because that was the foundation for social transformation. But later, as the conflict between authorities and self-organized society intensified and economic crisis grew, it became apparent to more and more people that some institutional transformation would have to be initiated to lead Poland out of the crisis.

To this point, Solidarity's transformation was above all "social," in that it allowed new actors to form and articulate interests. Now, however, these actors had to reconstruct the more durable rules and patterned distribution of resources that shaped still the interaction of these old and new groups. The intelligentsia was more active in promoting this institutional reform of economy and politics than workers. For instance, the self-managing movement called Sięc, or the Network, was above all led by engineers and other professionals, even if in alliance with workers. Too, the Solidarity Congress in the fall of 1981 was devoted most of all to political issues, and most of the delegates were themselves from the intelligentsia. ${ }^{35}$

Although internal politics may have grown more divisive over time, Solidarity was characterized by an internal discourse that reproduced the unity of the movement. ${ }^{36}$ Realizing the importance of the workingclass base, intellectuals would rarely formulate plans that contradicted the workers' egalitarian orientations. For example, the formulation of 
the self-management project was not justified solely in terms of economic necessity or efficiency, as in isolation engineers may have done, but also in terms of democracy. In this sense, self-government as a democratic ethos was extended downward to that of the enterprise, as intellectuals had moved it upward to the national level. Pluralism also remained one of the movement's fundamental values, in terms of the alternative order for which Solidarity struggled, but also in terms of the struggle itself as each social group was encouraged to form its own identity to represent its own interests. Pluralism was thus understood as social self-organization, even while fundamental disagreements were suppressed in the attempt to preserve the solidarity of civil society against the state. An internal pragmatism based on the values of selforganization, equality, and self-government enabled Solidarity's activists to continue the construction of a cross-class movement.

This pragmatic cross-class movement had its systemic foundations too. By itself, the intelligentsia did not have the social power to effect the institutional transformations they sought. They could not end nomenklatura, promote greater professionalism, or open the public sphere without the pressure brought by the threat of collective action by workers in Poland's largest factories. In this sense, the intelligentsia was dependent on workers to effect social reconstruction. Thus, the discursive reproduction of Solidarity's unity was premised on the dependency of intellectuals on working-class power. ${ }^{37}$

This reproduction of movement unity was, admittedly, becoming more difficult to realize over the fall of 1981, but it had by no means yet failed. Nevertheless, the imposition of martial law on 13 December 1981 prevented Solidarity's politics from moving in any direction generated by the movement's original form. Solidarity's cross-class unity had been reproduced pragmatically in an open public sphere. Once that sphere was closed, Solidarity became but a symbol, and an ambiguous one at that.

This experience of an open public sphere in 1980-81 demonstrated to most that the defense of civil rights and self-organization could not serve as an adequate frame for systemic transformation (as in the economy or polity) even if it could generate a marked social transformation (as in the formation of new groups to defend civil liberties). When debate over institutional change moved to the center, this of necessity led to the construction of a more pluralistic Polish opposition, and a more pluralistic Polish politics. I shall return to the Polish case later in 
this essay, but I should turn to the opposition which, by contrast, began as a pluralistic body, even if more exclusively intellectual.

\section{The difference between Poland and Hungary}

The arguments of opposition intellectuals in Eastern Europe reflect both the social conditions in which they are constructed as well as the legacy of oppositional activity upon which they draw. The difference between Hungary and Poland can, perhaps, be most clearly drawn by considering why one such argument, Konrád and Szelényi's thesis of the intelligentsia as a ruling class in statu nascendi, could be considered appropriate to Hungary while unsuitable for Poland.

At the very time Konrád and Szelényi were writing of the likelihood of the political authorities and intelligentsia finding common ground for class rule, the Polish intelligentsia was beginning to reconstruct a moral/cultural basis for opposition to the communist authorities. Indeed, Frentzel-Zagórska and Zagórski's critique of Szelényi rests on such an account that finds no reason to elevate imputed class interests above cultural self definition in the explanation of class alliances and social conflicts. ${ }^{38}$ In Hungary, the constitution of social groups prohibited the same kind of dichotomous politics of morality as that created in Poland. There are three basic sociological reasons for this.

First, and most obvious, Polish workers have been more militant and more organized than any other working class in Soviet-type societies. When Michnik could write in 1976 that open social conflict proves both revisionists and neo-positivists wrong, intellectuals in other East European countries had no basis for expecting such open or protracted social conflict. Before 1989, revisionism and especially neo-positivism were not strategies that could be thrown on the ash heap of history in these other countries. Indeed, while Michnik in 1976 was speaking of the importance of a program that could avoid compromise with the authorities, over a decade later János Kis was writing that "the resolution of the country's crisis is conceivable only in the form of compromise." 39

Second, and not unrelated to this first point, the disparity between public façade and private disposition among intellectuals has likely been greater in Poland than in Hungary, though perhaps not greater than that experienced in the early $1960 \mathrm{~s}$ in Czechoslovakia. ${ }^{40}$ The cul- 
tural gulf between communist authorities and independent intellectuals is greater where intellectuals do not practice the politics of revisionism or of neopositivism. It is also greater where nationalist traditions are posed in overt opposition to the communist regime.

In the mid to late $1970 \mathrm{~s}$ in Hungary, some of the most prominent opposition intellectuals were students of Lukács, and were still working out their relationship to the Marxist tradition. By contrast in Poland, few if any opposition intellectuals accepted Marxism as a primary tradition by the late 1960s. Where in Poland nationalism was situated in revolutionary opposition to the regime,${ }^{41}$ in Hungary the populist tradition worked relatively comfortably with the communists through the mid 1980s. ${ }^{42}$ Indeed, it was not until the mid 1980s in Hungary that a group of reformers broke with the establishment to address society rather than only official decision makers ${ }^{43}$ whereas in Poland, that break had perhaps taken place in 1968 and certainly by 1976 . For the Hungarian intelligentsia, the field of intellectual politics was not so antagonistic as in Poland, and compromise involved in working for the regime was not so problematic.

Third, the Hungarian authorities have been much more skilled at dealing with intellectuals, especially those in Budapest. They assured more space for intellectual independence than the Polish authorities, and even when they censored their intellectual opposition, the Hungarian authorities were more limited than their Polish comrades. Their attack in the early to mid 1970s on independent intellectuals was more selective and careful than the broad attack on intelligentsia and students that the Polish authorities engaged in 1968 , and certainly not so severe as that repression Jaruzelski's martial law represented. And since the 1974-75 trial of Miklós Haraszti, intellectuals had not been subject to any criminal proceedings, ${ }^{44}$ although in the late 1970 s several leading independent Budapest intellectuals were pressured to emigrate ${ }^{45}$ and in the early 1980 s, independent intellectuals were harassed with administrative fines. ${ }^{46}$ While in the early 1980 s people were in jail for political reasons, they were not the Budapest opposition intellectuals. ${ }^{47}$

These three social conditions distinguished Hungary from Poland (the demobilization of the working class, the legitimacy of compromise, and the manipulative skill of the authorities) were fully developed in the 1980 s, even though they were already apparent in 1968 when the regional planners' project inspired Konrád and Szelényi's new class thesis. ${ }^{48}$ Although Polish sociologists would have been unlikely to 
entertain such a thesis in the beginning of the 1970 s given working class mobilization, Gierek's technocratic consumerist socialism might have made it an appealing thesis had the Polish communist succeeded. But his initial failure in the middle of the decade and Solidarity's emergence in 1980 made the new class thesis seem inappropriate to Poland, considering workers' mobilization and the regime repression and the illegitimacy of compromise that followed. Szelényi himself began to back off from such a thesis in the mid 1980s (1986-87), but by decade's end he found ample justification in the new Hungarian politics to argue that the intelligentsia might just have won class power, if the discourse of the day was any indication. ${ }^{49}$

These three social conditions differentiating Poland from Hungary are themselves associated with the opposed experiences these societies had in the revolutionary year 1956. For Poland, 1956 was initially a year of triumph, a time when Polish party authorities defied Soviet authorities, opened new cultural boundaries, ended experiments with agricultural collectivization, established better relations with the Catholic Church, and legalized greater workplace democracy through workers councils. Even if this "Polish October" led to disappointment a few years later, and outright rejection by 1968, it was a far cry from the total defeat that 1956 signified for Hungary's opposition. Even more significant than the outcome of 1956 , however, was its relationship to the 1980 s in these two countries.

By 1980 in Poland, 1956 barely figured into the opposition's consciousness. The legacy of workers' councils and revisionist Party politics was far less important to consider than the issues raised by the 1968, 1970, and 1976 events, which involved independent trade unions, the role of the opposition intellectual, and the making of civil society. These was the decisive generation making events for the opposition of 1980 , and it was their legacies Polish intellectuals were obliged to discuss. But in Hungary the legacy of the 1956 revolution continued to shape the politics of opposition intellectuals and of civil society through the end of the 1980s. János Kis, one of Hungary's leading democratic oppositionists, wrote of 1956-57 in 1987:

Hungarian society has yet to come to terms with the total defeat it suffered at that time, and those in power have yet to overcome the burdens of their victory. The economic crisis which in the 80's overwhelms Hungary is the crisis of the restoration regime which came into existence thirty years ago.... Today we must remember the restoration not just in order to regain moral integrity, but in order to understand the present political crisis of the regime. 
We have to analyze former (failed) proposals of conciliation in order to find a more effective compromise to our present and future (perhaps less hopeless situation). The events of 1956-57 developed from a moral issue into a political one. ${ }^{50}$

Kis's analysis of that period clearly informs, and reflects, the Hungarian political strategy of the $1980 \mathrm{~s}$. He follows a form of historical explanation based on radical contingency rather than deterministic logic. He emphasizes how various "accidents" shaped subsequent events in 1956-57. For instance, had there been no Soviet tanks introduced to Budapest on 23 October, a new government under the aegis of the People's Patriotic Front might have been formed and a multi-party system not become inevitable. ${ }^{51}$ Or when the Kádár government took power with the aid of Soviet tanks, the Kádárism of that period (understood by Kis as three planks: the public display of party unity, the political neutralization of society, and the refusal to recognize any extra-Party negotiating partner ${ }^{52}$ ), could have been replaced by the retrieval of Stalinists or by a negotiated compromise with Imre Nagy. ${ }^{53}$

This kind of historical explanation encourages the adoption of a political strategy based on compromise rather than fundamentalist politics. In particular, Kis studies the strategies of the workers' council movement as examples, especially significant given that they survived the formal restoration of the Kádár government in Budapest on 7 November. The peaceful resistance by the Greater Budapest Central Workers' Council, formed on 14 November, was the first exemplar of sophisticated compromise politics, where they gradually dropped their demands for the restoration of the Nagy government and multiparty system as well as the departure of Soviet troops in favor of promoting the self-organization of workers' councils as well as council access to an open public sphere. ${ }^{54}$ The Stalinist wing of the Party had grown increasingly strong toward the end of November, and provoked enough violent conflict to end the possibility of negotiations with politically minded workers councils. The second phase of council resistance was dominated by the Csepel Iron and Metal Works workers council, which had advocated a less political function for councils, and took the restored Kàdárist regime as its point of departure, not the ideals of the Hungarian revolution. But by $8-11$ January, the possibility of even this kind of compromise was ruined by the increasing hard line of the Kádárist government, and the violent suppression of a strike by that factory's workers. These compromise strategies might have worked, he thinks, had the international scene and internal conflicts been different. 
Nevertheless, the sophistication of these council activities suggests to him that "modern society possesses the political capacity for the practice of an effective democracy" given that these councils were led by workers and engineers. ${ }^{55}$ But the legacy of 1956 has destroyed that democratic capacity already proven. To cope with the demand Kádár made, that society "forget" its experience in return for material compensation, ${ }^{56}$ society had to withdraw into private life. Under these circumstances, Kis writes, ${ }^{57}$

\footnotetext{
Whether a privatized society identifies with its defeated struggles or tries to forget them depends decisively on what its spiritual leaders - writers, jounalists, artists, historians, priests, teachers - articulate. They, after all, are in the position that, by virtue of their profession, their words and silence constitute a public statement. It depends on them to decide if they will provide symbols of loyalty and models of endurance to be emulated. In Hungary, this stratum did not supply society with the instruments to enable it to remain loyal to its revolution while making peace with reality. Indeed, the selfsame intelligentsia evolved into the source and foundation of the consensus that insists that the cultivation of intellectual opposition is a 19th century romantic pose and inappropriate to Realpolitik.
}

Indeed, even Kis, himself an important part of that intellectual opposition, was too Realpolitik for the events that would soon transpire. In a sense, while the social conditions continued to inform the 1989 revolution, the lessons of 1956 soon became quite irrelevant. Compromise gave way to revolution. But while the strategy of compromise in social tranformation proved outdated, his identification of principal actors remained accurate.

\section{The intelligentsia's creation of Hungarian civil society}

Although the 1956 revolution was a genuinely popular uprising, its brutal suppression left the popular classes demobilized and depoliticized.$^{58}$ For over two decades, one could not even speak of an "opposition" in any significant sense, in which time Poland had already gone through two major working-class rebellions and several protests by intellectuals. There certainly were independent dissident intellectuals, as the layoffs and forced emigrations suggest. But an organized opposition politics only returned to Hungary in 1977.

In January of that year, 34 intellectuals signed a letter, published in the western press, indicating their solidarity with the principles of the 
Czechoslovak group, Charter 77. Human rights and civil liberties, as in Poland the previous year, had become the language of opposition in Czechoslovakia, and now in Hungary too. Pierre Kende describes the Hungarian signatories as "critical" marxists, students of Lukács, who were young and "highly intellectual but not very political." ${ }^{59}$ What is more, a significant number of them belonged to the Budapest Jewish intelligentsia and had been dismissed from their university posts earlier in the decade. While the Polish regime launched a selective and relatively brutal campaign against the working class and intellectual opposition after 1976, in Hungary the authorities decided to ignore the January action by this small group of intellectuals.

In the succeeding years, opposition activities remained largely the province of relatively elite intellectuals and students. There were the publication and distribution of samizdat materials as well as "private" conferences on taboo subjects. The line between opposition and official activities was sometimes quite blurred, given the use of public facilities for activities that themselves could have merited oppositional status. ${ }^{60}$ A group of populist poets raised the most significant cultural issue of this long decade of Hungarian dissent: the fate of Hungarians living in Czechoslovakia, Yugoslavia, and especially Romania.

The activities of intellectuals did not just involve talk, however. One group, students of the exiled sociologist István Kemény, also initiated an innovative campaign in 1979. They established a private charity called Sz.E.T.A. to help the poor. This was oppositional only in the sense that official rhetoric recognized no poverty in the system, and provided no particular relief for them. The authorities finally dealt with this strategy by acknowledging poverty and introducing a policy to help the poor. Independent political action took new forms too.

In 1983, the election law was changed so as to require multiple lists for candidates to the Parliament. In 1985, in the first elections to be affected by this law, only two independent candidates were finally elected, a journalist named Zoltán Király and László Csoma, director of the Keszthely local museum. A few Party-sponsored deputies, most notably physician Erika Tomsits, asserted their independence too, however, and together with Király formed an informal but independent caucus within the Assembly. In general, János Kis found most of the Assembly mentally impoverished, unable to form a "comprehensive understanding of the issues." ${ }^{\prime 61}$ But Király and Tomsits represented the kind of people necessary for Hungary's public revitalization: "politically- 
able legislators who have not yet been elevated into the official hierarchy of positions, ranks, and titles," those who had the political vision that could enhance the National Assembly's position so as gradually to transfer national affairs from behind Party doors to the public arena. ${ }^{62}$ But they could not do that alone, and certainly not without help from independent social movements, he argued.

At that time, it appeared that Hungarians had the compromise politics that might enable negotiation, unlike Poland. But they did not have the social movements like Solidarity that could force negotiations. Nevertheless, over the decade, a growing number of movements did become rather significant, even if they remained the province of the intelligentsia and those who anticipated joining its ranks.

Spontaneous demonstrations led by students took place with growing intensity over the $1980 \mathrm{~s}$, with the anniversary of the 1848 revolution, 15 March, serving as a regular spark. An independent peace movement called Dialogue also was formed by students in 1983 in order to challenge the official peace movement. Although its members also tried to remain distinct from the opposition, it was finally repressed by the government in August 1984. Perhaps the largest and most significant independent movement was formed later that year, led by members of the scientific intelligentsia. The environmentalist group called the Danube Circle was established to oppose the construction of a dam by Czechoslovak and Hungarian authorities on the Danube River. The long decade of Hungarian dissent, from 1977 to 1988, thus saw a proliferation of a new independent politics, even if they were restricted mainly to the intelligentsia and students. ${ }^{63}$ The political revolution of 1988-89 was also carried out mainly by the intelligentsia, in two dominant currents. ${ }^{64}$

The populists were numerically the largest group, and hardest to define formally. Five of its nine founding members were poets and writers. They identified their movement with the needs of the Hungarian nation, defined ethnically or racially. They generally spoke of the "third road" between capitalism and communism. The authorities had cultivated them as an ally, especially since the 1956 revolution, although in the mid-1980s the populists began to identify with some projects of the democratic opposition. The populists formed the Hungarian Democratic Forum in 1987 and generally avoided technical programs for economic transition in favor of literary emotional politics. They prefered "intuition to analysis, and literature to social science." ${ }^{65}$ Until the 
November referendum on the timing of the Presidential election, they were the most successful in Hungarian transition politics, having won each of the four elections in the summer of 1989. They finally won the spring elections in 1990 and together with the Smallholders and Christian Democrats formed the governing coalition in mid-1990. But in the beginning of the revolution, they were the most closely allied with the reformist Party leader, Imre Pozsgay.

The other significant group of intellectuals in the 1988-89 revolution was called pro-western, democratic, liberal, and urban. Many had their origins in the Budapest School of critical Marxism, and many were of Jewish descent. From 1981, their main efforts were directed toward the independent journal Beszélo, but in 1988 they formed the Alliance of Free Democrats. Their program for institutional reform was generally considered the most elaborate and formally specified of all the opposition. They were often allied informally with reformers within the authorities, especially the reformist legal experts and economists. Many other political parties and social groups have formed since 1988, but these two represented the significant intellectual tendencies in the politics of the 1988-89 Hungarian revolution. That was reflected in the spring 1990 elections as these two parties received the most votes.

The populism of the Hungarian Democratic Forum reproduced the traditional form of Hungarian twentieth-century nationalism. Above all, they were concerned with the fate of the Hungarian minorities living abroad. They also promoted the idea of Hungary being somehow special and in between the west and east, deserving its own unique identity based on an independent small-holding peasantry. But by 1989, their emotive program did not suggest as radical a transformation of the Soviet-type system as the Free Democrats, for the main question of instititutional transformation was not based on cultural questions or even agriculture's ownership. The Soviet-type system's main antagonist had become the institutionalization of free marketbased civil society, and it was the Alliance of Free Democrats that promoted this as an alternative to the Forum's populism, and as the means for the transformation of the Soviet-type system.

This group had already begun to move down that liberal road in the beginning of the 1980s. Much as in Poland, civil society became the principal alternative politics of emancipation to that of nationalism. To struggle in the Soviet-type system for the rule of law rather than of the Party, for free associations instead of Party-sponsored organizations, 
for freedom from censorship and a multi-party system provided Hungarians, like Poles, with a coherent tranformative strategy that did not have to elevate one's nation above others. György Konrád expressed this simply: ${ }^{66}$

\begin{abstract}
We want that internal process with which East Central Europe is already pregnant; we want bourgeois civil liberties and an embourgeoisment that is not hedged about with prohibatory decrees. We don't want the authorities to have discretionary rights over us. We want constitutional guarantees; we want it clear that semifreedom is not freedom, half-truth is not truth, liberalization is not liberalism, democratization is not democracy. We want no less than what the most advanced democracies already have.
\end{abstract}

Unlike the Polish, however, this Hungarian project was not very successful in providing a program that mobilizes those who are not from the intelligentsia. The groupings discussed above were mainly from that class, and if not, as in the Populists, they were nevertheless led by intellectuals. Two illustrations can further illustrate the intelligentsia's hegemony in the creation of Hungarian civil society.

\title{
The character of self-organization in Hungarian civil society
}

On 30 March 1988, thirty-two young intellectuals, students, and workers (although mainly law students) established FIDESZ, or the League of Young Democrats. The Hungarian acronym was designed intentionally to resemble the Latin fidelis, to symbolize the group's aim and character. FIDESZ was designed as an independent youth organization that would fill the gap left by the Party's youth organization. It was formed on the basis of an imagined civil society, in order to make civil society more real. Following Hungarian postwar political theorist István Bibó, they argued that the law should be made to control the state and its rulers, rather than made to control the people. It argued that the opposition should take rights guaranteed by the constitution seriously, and thus treat the law as if it, rather than the Party, ruled. On that basis, FIDESZ used the constitutional guarantee of association to defend their formation. Their leaders were arrested, and legal proceedings were begun against them. But in the three months of trial, the group grew to more than two thousand members nationwide. They lost the trial, but they ultimately won. In January 1989 legislation was passed in the Hungarian parliament that guaranteed their rights of assembly. ${ }^{67}$ 
As a movement of students and young intellectuals, FIDESZ did not claim to represent other classes. The group was mainly symbolic and exemplary, hoping that through their own civil disobedience and pressure for the rule of law others might learn how to exercise their own rights. These activists believed that civil society and the rule of law would represent the interests of everyone, so long as people could learn to exercise their rights. FIDESZ activists ultimately would not only seek election to Parliament but also try to promote a broader awareness of legal rights and possibilities to workers and especially peasants. FIDESZ thus represents the new "classless" universalism suggested by civil society. For these young lawyers, the emancipatory alternative is a law-based society in which individuals understand their legal rights and are ready to engage them, and where people's economic needs would be satisfied by their participation in a free market of goods and services. ${ }^{68}$

This self-organization and transformational praxis represent the hegemony of one relatively elite part of the intelligentsia. Formal equality before the law carries, of course, many of the limitations on democracy Marx noted long ago, ${ }^{69}$ but that is not the only problem. Because peasants and workers were not engaged in the creation of this civil society project, they have left a weak imprint in the constitution of the new Hungary. Furthermore, although activists claimed that they would enter the lifeworld of peasants and workers to explain to them their rights, their preeminent struggle has been to assure this legal state and their place in it. Given that struggles for power in this new state have taken precedence, popular movements were not engaged except as voting masses to be swayed, rather than as program making actors in their own right. Indeed, as the media campaigns for the elections showed, the "public arena" created by the 1988-89 revolution resembled more the public-relations market of U.S. capitalism rather than the civil society idealized by the Hungarian democratic opposition.

This transformational praxis should not be understood as a project of the entire intelligentsia either insofar as the economic interests of many intellectuals require far more than "neutral" law-based market society. Much as for other employees of the Soviet-type state, the intelligentsia needed an independent trade union.

Given the experience of Polish Solidarity, independent trade unions might have suggested an alternative future for Hungary, but even they were overwhelmingly from the intelligentsia. On 16 May 1988, the first 
independent trade union, the Democratic Union of Scientific Workers, representing those who work in the nation's research institutes, was founded. They followed a similar strategy as FIDESZ in their founding, by acting as if a legal state existed. Because the Hungarian Constitution and labor code had no guidelines about the registration of unions, and because Hungary accepted the International Labor Organization's statements on freedom of association, the Union argued that it had the legal right to form. ${ }^{70}$ Other unions of the intelligentsia were formed in its wake, including those of filmmakers and teachers. The principal affiliates of the federative Democratic League of Independent Trade Unions, founded on 20 December 1988, also were white-collar unions. ${ }^{71}$ Urban speculated that blue-collar workers resisted this independent union organization because a) they still feared the government; b) they were divided by opportunities in the second economy; c) they feared the generation of Polish economic conditions; and d) they could not unify behind any ideology, positive (Catholicism) or negative (anti-Party), as Polish workers could. ${ }^{72}$ One should add that the old communist unions, in alliance with the "red barons" or large enterprise managers, continue to exert influence over the distribution of resources, and therefore proved more sensible organizations for workers from the largest enterprises. ${ }^{73}$

Although the personnel of the trade unions further illustrated the hegemony of the Hungarian intelligentsia in the making of its civil society, the union movement could have had different consequences than other organizations of the intelligentsia. Their unionization reflected the homogenization of intellectuals in the Soviet-type system. The intelligentsia was not organizing on the basis of its distinction, nor on behalf of some universal principle of civil rights or national interest. Instead, it organized on behalf of its own self-defense, much as any other group in Hungarian civil society would have. And to assure its self-defense, it would have been obliged to act more like state "employees" than independent intellectuals, establishing alliances with other employees. If that had occurred, they might have served a functionally analogous role as organic intellectuals in capitalist society, or professionals in Solidarity. But without other independent unions having been established, and because peasants and workers were not well represented in such a federation, this union of members of the Hungarian intelligentsia represented only the continuation of the intelligentsia's hegemony in civil society rather than the popularization of civil society itself. 
This union strategy may have led to the creation of a more popular civil society had the authorities not followed the strategy they did, however. Instead of forcing the hand of the popular classes, the authorities prevented their mobilization by negotiating the post-communist transition with the intelligentsia who made civil society.

\section{Hungary's post-communist transition}

The hegemony of the intelligentsia in the construction of Hungarian civil society was not only apparent in the personnel of its associations or in the philosophies of its proponents. Hungary's political revolution was itself derived from the interactions of this intelligentsia with Party officials, in typically intellectual forms: conferences and publications.

The most proximate foundation for the political revolution was Hungary's economic crisis. Although not so obvious as that in Poland or Romania, by the early 1980s Hungary was in a dangerous economic situation with the highest debt per capita level in Eastern Europe. But this crisis need not have laid the foundations for dramatic change. Tamás Bauer, one of Hungary's leading reform economists, argued that Hungary's economic reform depended on three conditions: (1) a crisis so profound as to convince both ruling elites and intellectuals that the command economy was failing, (2) the existence of a "more or less free intellectual community of economists" and (3) "the readiness of both scholars and government experts to cooperate and make the necessary compromises." ${ }^{74}$ Economic reform in 1968-1972 had been shelved in Hungary, even if the reform economists themselves remained in their positions. Economic reform therefore depended on the autonomy of economists and the willingness of political authorities to respect their independent expertise. It depended on the restoration of the intelligentsia's traditional position of autonomy and authority. But the intelligentsia won this authority not because of tradition or because of their special talent but because of the dynamics of change in the Party itself.

In the spring of 1986, Imre Pozsgay, then General Secretary of the Patriotic People's Front, requested that reform economists produce a report on the economic crisis. ${ }^{75}$ Published in 1987, this report, entitled "Turnabout and Reform," documented the economic crisis and proposed solutions that were heretofore only discussed in samizdat form. ${ }^{76}$ This report was used later by Károly Grósz to oust longtime leader János Kádár. ${ }^{77}$ Thus, intellectuals were still perceived as instruments to 
be used by the authorities in their own struggles. But this political opening enabled intellectuals to move toward the establishment of a more autonomous politics too.

In June of the same year, the democratic opposition published in the samizdat journal Beszéló an article called "The Social Contract," in which they called for political pluralism with an independent parliament and freedom of the press, although not yet a multi-party system. Later that fall, the populists held a meeting where they established the Hungarian Democratic Forum. Significantly, Pozsgay was there attempting to establish his base outside the party. In effect, a small group of Party reformers had intended to use this mobilization of reformist economists, populists, and democratic opposition to change the Party leadership and they finally succeeded.

By May 1988 Kádár was ousted from his position. Károly Grósz was but an interim leader, however, as his indecisiveness and inability to win significant improvements for Hungarian minorities living in Romania undercut his position. ${ }^{78}$ Between the fall of 1988 and winter of 1989 the Party reformers steadily improved their position within the Party. Simultaneously, Party rhetoric came to accept more and more the prospects of a multiparty system, even if still incorporating Communist Party leadership. But the opposition organized itself into a new body that spring that effectively undermined even this radical reformist strategy.

The Opposition Round Table ${ }^{79}$ was formed on 22 March 1989 in order to assure that negotiations with the authorities would not be manipulated to allow the Party unfair influence over the structure of the talks and their outcomes. Thus the foundation on which the Party reformers thought to extend their influence, independent associations of the intelligentsia, became instead the vehicle of an autonomous civil society that would negotiate the establishment of a multi-party political party system and inspire the dissolution of the Hungarian Socialist Workers Party itself. ${ }^{80}$

In contrast to the popular perception of negotiations in Poland, the Hungarian roundtable could claim to represent formally less than 1 percent of the Hungarian population. ${ }^{81}$ Nevertheless, the Hungarians negotiated a more complete revision of the Soviet-type system than the Poles. Although this could appear as a paradox, ${ }^{82}$ it is quite sensible if this class bases for civil society are kept in view. The Hungarian politi- 
cal revolution of 1989 engaged only the intelligentsia, and therein a tacit alliance with Party reformers. Hungarian civil society was partially restored because the transformation was wrought from within the incipient ruling class of former Party bureaucrats and intelligentsia. The Polish case seemed to have promised something different with the struggle of Solidarity, even if it ultimately became a variation on the Hungarian theme too.

\section{Poland's post-communist transition}

Solidarity's very size and heterogeneity meant that it could have represented different things to different people. Certainly once it evolved beyond a defensive strategy for self-organization and toward a program for institutional reconstruction, a lively politics within the movement was healthy if not inevitable. But for the movement to survive as a total movement of civil society against the state, debate had to respect the anchorpoints of Solidarity's self understanding in self-organization, equality, and self-government. In 1980-81, dialogue, both explicit and implicit, reproduced these values within this cross-class movement.

The imposition of martial law destroyed the possibility for that continuing dialogue, however, and with it the cross-class quality of the movement. The public sphere shrunk, as most people retreated from politics. This sphere retreated unevenly, as the intelligentsia was more likely to remain actively engaged in politics than were workers. The distinction of the Solidarity movement thus began to fade. The pragmatic construction of a political movement that embraces equality, pluralism, and self-management as a condition of cross-class unity depends on an open public sphere with broad cross-class participation. This breadth could not be preserved under conditions of martial law and its aftermath. This new, uneven participation has several social foundations. ${ }^{83}$

The Polish authorities treated workers and the intelligentsia differently during martial law. On the one hand, the authorities established new unions that promised to realize many of the employees' demands for which Solidarity struggled. Although these new unions never won the support, especially among skilled workers in larger factories, that Solidarity did, the new unions were especially uninfluential among the intelligentsia and the fields they dominated: the health sector, the cultural establishment, and universities. ${ }^{84}$ 
On the other, the authorities treated workers more harshly than the intelligentsia for oppositional politics. When interned, members of the intelligentsia were generally housed separately from workers, and treated better. The oppositional activities of workers also were more strictly curtailed. Strikes in enterprises were treated more harshly than the actors' and writers' boycotts. Efforts by physicians, teachers, academics, and artists to establish a more open field of information and culture went relatively unhampered. The Minister of Culture even said that while they did not support it, they didn't go out of their way to persecute the underground press either. ${ }^{85}$ It is not surprising, therefore, that workers' oppositional politics declined more dramatically than that of intellectuals. This unevenness has had devastating consequences on the class character of the opposition.

The social distance between classes grew in this period. Many in the intelligentsia were angry with workers for having failed to mount greater resistance to the regime. Negative stereotypes of workers became more common. ${ }^{86}$ Solidarity also began to be criticized for having been too socialist, too "workerist." ${ }^{87}$ The response of workers to this criticism was ambivalent. On the one hand, they again began to identify the intelligentsia with their supervisors rather than with themselves. On the other, they began to rely on intellectuals more for maintaining the opposition. ${ }^{88}$

The intelligentsia realized this responsibility, but also assumed greater autonomy from the existing factory-based movements among workers. The anchorpoints of Solidarity's self-understanding, in social self-organization, equality, and self-management, were no longer decisive in defining the programs of the opposition, as the intelligentsia was no longer dependent on workers. Drawing upon the symbolism of Solidarity if not its organization, intellectuals could now claim to represent workers, but only as they represented the Polish nation.

The opposition fragmented into several currents. Smolar ${ }^{89}$ identified the mainstream opposition with Watessa, Solidarity, and the Temporary Coordinating Commission. Smolar called realists those who considered it ineffective to continue to press for Solidarity's relegalization, and advocated coming to terms with the system. Smolar recognized another wave as radical for its greater demands than that of the mainstream, pressing for some kind of political revolution in Poland. Finally, another tendency noted by Smolar was that characterized by the politics of youth, who rejected old formulations and sought a new politics 
resembling more anarchism than socialist or labor politics. Intellectuals could be found constructing all of these currents.

The regime itself clearly tried to shape oppositional politics. It treated most harshly those like Kornel Morawiecki of Fighting Solidarity, Leszek Moczulski of the Confederation for an Independent Poland, and others who advocated some kind of revolutionary, even if non-violent, politics. It lambasted the youth-based, independent peace movement WiP as traitorous to Polish society. It imprisoned those unionists who advocated more confrontational politics, while allowing those, like Bujak, who advocated dialogue, to continue their underground existence. ${ }^{90}$ It also encouraged the realists by offering selective inducements for cooperation.

For those most willing to cooperate with the regime, Jaruzelski established a "consultative council," with about one-third of its members from the regime, one third from Catholic circles and one-third independent intellectuals. This council, established in 1986, did not gain widespread social support and only a few prominent intellectuals, including lawyer Wladysław Sina-Nowicki and writer Andrzej Swięcic$\mathrm{ki}$, joined it. The authorities also sought to promote a more independent opposition, so long as they remained "pragmatic," or respectful of Poland's system and geopolitical realities. The best example of this is their permission for the establishment in 1987 of the first independent, non-religious periodical in the Warsaw Pact, Res Publica. Although still subject to censorship, the publication pursued its liberal democratic themes vigorously.

The regime also encouraged another kind of realism attractive to members of the intelligentsia among others. It facilitated the promotion of a new patriotic politics, based on the spirit of entrepreneurialism. Although its promoters included several former worker activists, this agenda was also anti-worker, arguing that the solution for Poland's dilemmas lies in the promotion of a free market economy and private enterprise based on the multiplication of wealth, not in the continuation of workerist politics based on redistribution. ${ }^{91}$

In effect, with these activities the Polish authorities were trying to establish a new modus vivendi between them and civil society. But this new agreement was not based on broad public participation, as Solidarity had been. Instead, it was to be based on a skewed participation, with workers returned to narrow union concerns, and the intelligentsia 
once again established as the representatives of the nation. One might say that the Polish authorities tried to reconstruct the Polish opposition in the Hungarian image. In so doing, the anachronistic status of autonomous intellectuals in communist politics was completely abandoned in the hope that the realism of such intellectuals could restore some measure of public consensus for the Polish communist order.

Although it has become new common wisdom that this strategy could not have succeeded, its failure does not have its main roots in intellectual politics. The main reason this strategy failed was that a new class of militant workers emerged to destroy this modus vivendi in the making. In May and August 1988, workers in Gdańsk and several other places initiated a wave of occupation strikes demanding, among other things, increases in wages and Solidarity's restoration. This movement was not, however, initiated by old Solidarity acitivists. This was a new generation of workers, who trusted few outside their immediate milieu.

The authorities were extremely apprehensive with this new wave of strikes, fearing they could not contain them. As such, the authorities had to abandon their strategy for promoting a new realism, and turn to another realism represented by the old Solidarity leadership. This leadership was, by now, relatively trustworthy in comparison to these new anarchistic youth. The authorities' only hope was that these former opponents could restrain workers from further strikes. In return, the Solidarity leadership demanded negotiations for Solidarity's legalization. This exchange resulted in roundtable negotiations that were organized in February 1989, and concluded in April.

The principal distinction of this mainstream Solidarity leadership from the realist opposition was that it insisted on Solidarity's legalization. In this sense, the "realists" were left behind in the roundtable negotiations leading to Solidarity's legalization. But aside from the question of whether independent trade unions were realistic or not, the realists and the mainstream of Solidarity shared a great deal in their vision of an alternative Poland. What nobody anticipated was the responsibility Solidarity would soon assume.

\section{The contingency of communism's transformation}

The Polish roundtable agreements were considerable accomplishments. Intellectuals from both Solidarity and the regime agreed to put 
the past behind them and to negotiate on the basis of Poland's alternative future. ${ }^{92}$ It was, after all, the past that most divided them. Both sides had come to recognize that some political compromise would have to be reached, with communists and Solidarity in government. Both sides too had come to recognize the necessity of fundamental market reforms in the economy. And by the time of the negotiations, the cultural sphere already had opened up such that there were small differences on matters of the present and future between underground publications from the Solidarity mainstream and those published officially.

There were, of course, important differences expressed within the negotiations. They were divided over what proportion of seats in the Sejm were to be allocated to the Communists and their allies. There were also sharp differences in the economic reform, over the degree to which wage increases would be pegged to increases in prices. But here, the official communist union associated with Alfred Miodowicz demanded greater wage compensation than either the Party or Solidarity. Miodowicz's group also demanded more egalitarian wage increases than Solidarity. Nevertheless, an agreement was reached that allowed open elections for all Senate seats and for 161 out of 460 seats in the Sejm.

The June elections turned out to be a landslide. To everyone's surprise, the Solidarity Civic Committee, associated with Lech Watessa and the mainstream Solidarity leadership, won every seat but one available to it. This new Sejm and Senate were then obliged to elect a President, who roundtable negotiators agreed would be Wojciech Jaruzelski. But those elected by Solidarity found themselves in a difficult position, for their electorate did not want the man who imposed martial law to be their new President. Nevertheless, by managing to be absent, a number of Solidarity legislators allowed the Communist-led coalition to elect Jaruzelski president. The Peasant delegation of this bloc, however, bolted in the next election as they refused to support Jaruzelski's nominee, Interior Minister Czestaw Kiszcak, as Prime Minister. The defection of the Peasant Party acivitists to Solidarity's side allowed the election of Solidarity advisor and Tygodnik Solidarność editor Tadeusz Mazowiecki as Prime Minister.

As in Hungary in 1988-89, there was a political revolution in Poland. In the roundtable negotiations, the Polish United Workers Party effectively ceded its monopoly of power to a government that they anticipated would still be Communist led, even if with a legal opposition in Solidarity. Due to the unexpected failure of the Party at the polls, the 
Party was obliged to establish a new political formation, with the Party as the leading partner in a coalition with Solidarity. But due to the unexpected assertion of independence by the formerly subservient Peasant Party, the only option left for this new government was to establish a Solidarity-led coalition, with Solidarity responsible for the economy and the Party holding cabinet positions overseeing the military, internal affairs, transportation, and foreign trade.

I began this article with one stated aim being the clarification of the contingency with which the transformation of Soviet-type society in Eastern Europe has been made. Of course most of the discourse around communism's end today is based on the system's inherent economic defects, or the vigor of the national cultures of Eastern Europe. The point missed by this emphasis is that the process of communism's collapse is not preordained by these structural factors. For Hungary, the smoothness of systemic transition was quite surprising and due in large part to the failure of the Party reformers to retain hegemony in roundtable negotiations, and even more surprisingly perhaps, in the efforts of the Party reformers to move transition ahead. ${ }^{93}$ This is perhaps less counterintuitive for Hungarian analysts, accustomed as they are to theories of change based on contingency. ${ }^{94}$ The appropriateness of a contingent theory of Polish communism's downfall is more controversial, given the dominant tenor of Polish analysis. ${ }^{95}$ But here, perhaps even more than in Hungary, contingency reigns in explaining the particular form of Polish revolution: from the formation of the crossclass movement, to its dissolution over the $1980 \mathrm{~s}$, to the failure of the incipient Jaruzelski alliance with intellectuals given workers' strikes in 1988, and most dramatically, the events of the summer of 1989 where Solidarity was thrust, however reluctantly, into power.

This image of contingency is reinforced by the apparent difference between outcomes in Hungary and Poland. The opposition that has come to power in Poland is more homogenous in its initial claim to a single organizational allegiance in Solidarity, which itself purports to be an organization with roots in the working class, while Hungary's opposition round table was pluralistic and based in the intelligentsia from the start. But to take account of the transformation of Solidarity's class base suggests a determinism that we might not otherwise recognize were we to rest only on Solidarity's self-presentation. The contingency then lies in the character of the opposition to communism and the form of its transition. The sequal to communism is structured by a more powerful determinism. 


\section{The determinism of post communism}

No longer is Solidarity understood, as Touraine et al. described it, as a trade union and movement for democratic and national independence. ${ }^{96}$ Solidarity's leading identity as trade union has disappeared. The union has not had the same success in organizing workers as it had in 1980-81. While in the beginning of the decade some 9.5 million people belonged to the union, by June of 1989 less than 2 million were paying union dues. ${ }^{97}$ What is more, Miodowicz claims that his postPZPR $^{98}$ unions have not been hurt significantly by Solidarity's relegalization..$^{99}$ By December 1989 he claimed the movement still had over 6.5 million members. Although these numbers have a less than obvious meaning given that his members need not pay any dues to belong, Miodowicz's position does represent something potentially significant in post-communist politics, a point to which I return.

Polish Solidarity can no longer be understood as a democratic union and social movement defending society, but rather is an elite association devoted to a state-level politics designed to move Poland toward becoming a "normal" country.

Solidarity became elite in two senses: first the class base moved from workers to intelligentsia, and second, the intellectuals who have come to represent Solidarity have a new status that separates them from their grassroots organization. The June election campaign was organized by Solidarity Civic Committees not elected by any formal body, much less by Solidarity's remaining trade-union base. They were, in addition, composed primarily of representatives of the intelligentsia. ${ }^{100}$ The candidates chosen to represent Solidarity were not elected either, and rather picked by Lech Watęsa and his closest advisors. Their most effective campaign element was a photograph of each candidate with Walęsa, below which was written "We must win." ${ }^{101}$ These new elite politicians also were overwhelmingly from the intelligentsia. Of Solidarity's 261 nominations, only 10 were of workers and 35 of individual farmers. In contrast, there were 22 professors, 50 engineers, 35 lawyers, 20 journalists or columnists, 16 economists, 14 teachers, 13 health care employees, and 1 religion teacher. ${ }^{102}$ This slate lost only one seat in the contested elections, and it was to a millionaire private entrepreneur, Henryk Stoktosa. In terms of the composition of their new parliaments, Poland and Hungary have reached some kind of convergence. Of 386 parliamentary deputies, no more than 10 percent can be considered as anything other than highly educated in Hungary. ${ }^{103}$ 
But the power of this convergence lies in more than the social composition of parliaments, and rather in the new power relations that shape the politics of its leading intellectuals. The vision of the future is one of "normalcy," in which the market economy has assumed pride of place.

One observer in Polityka was struck by the change in the discourse of Solidarity leaders. Instead of themes like self-management, Solidarity leaders speak of company partnerships (spótki) and "joint ventures" (even rendered by Poles in English); instead of social self-organization they speak of the breakup of state monopolies in the economy. In general, instead of solidarity amongst people, Polish journalist Jerzy Baczyński finds social disintegration, where speculation and the privatization of state property into the hands of the old nomenklatura characterize the new themes of "cooperation." 104

This of course should not come as a surprise, given the shift in discourse over the 1980s described above, and the tenor of discussion at the Roundtable Accords at which both communist and Solidarity economists agreed that market reform was essential. ${ }^{105}$ There were disagreements over how radical the shock to the economy had to be, but there were no major differences about the direction of the economic reform. But as the rest of Eastern Europe broke away from communism, the race was on to get away from the system's economy.

In one important sense, Hungary was in the lead from the beginning. Hungary's second economy and cadre of "socialist enterpreneurs" was probably better developed than any other Soviet-type society, ${ }^{106}$ and if the formation of a domestic middle class of entrepreneurs is essential for the making of transition (as most sociologists from Eastern Europe today argue), Hungary has then the best social infrastructure. It has also developed a better array of financial institutions that convey the impression of taking the lead, for instance with "simulated" stock exchanges, joint stock companies, and capital markets. ${ }^{107}$ But Poland's "shock therapy" in the program for economic tranformation has received far more official applause and attention from the West.

The program for reform, under the authorship of Leszek Balcerowicz, was designed first to stabilize the economy and then institutionalize a complete privatization and marketization of the economy. The first stage was concerned above all with balancing the state budget and bringing the official rate of exchange closer to the black market one. In 
the second, more dramatic stage, on 1 January 1990 prices on most goods and services were liberalized while wage increases were severely limited. This led to high inflation ( $79 \%$ in January) initially, but by March inflation was down to $5 \%$. Poland has also made the privatization of its largest firms a priority. ${ }^{108}$ For these indicators of financial progress and promises of property reform, the Paris Club in the spring of 1991 forgave $50 \%$ of the debts owed by Poland to member governments (close to $\$ 33$ billion) and when Lech Watessa visited the United States, President Bush announced an even higher percentage to be forgiven by the U.S. government with $70 \%$ (but only $\$ 3.8$ billon), subject to a favorable review of Poland's reforms by the International Monetary Fund. Thus, even while foreign investment has fallen far short of most economists' anticipations in all of Eastern Europe, attention to the West's principles and standards of economic reform does pay off, at least for Poland. Given the assurances that Poland is a special case and such debt reductions are not to be repeated, we might say that Poland has won at least this leg of the race.

This shift in East European politics, away from overthrowing the communists and toward instead a race toward actually existing capitalism, reflects important changes in the East European intelligentsia, and has had important consequences for them too.

Unlike their reaction to communism, which the East European intelligentsia always treated as an unnatural Soviet imposition on their lifeworlds, the intelligentsia by and large has come to accept actually existing capitalism as the only alternative for Eastern Europe. They are tired of utopias and they want, as Konrád wrote about civil society, only what the West already has. And for that they look to their own intellectual representative of Westernization: the professional. The role of the intelligentsia, while remaining considerable in the transition to a post-communist order, is thus tranformed. In particular, those with legal and economic expertise will assume a new importance in designing the framework within which the alternative will be constructed. Economists and lawyers, rather than historians and journalists, will become the intellectual notables. For intellectuals without such claims to competence, they will be assured of continuing leadership only insofar as they become, on the one hand, members of a new middle entrepreneurial class, as software designers or new manager entrepreneurs, or on the other hand, as professional politicians in alliance with, or maybe even subordinate to, domestic and especially international capital. Thus, while the structure of the Soviet-type system moved the intel- 
ligentsia to opposition and the first post-communist authority, the new roles expected of them will undermine the teleological distinction and power of their class.

The East European intelligentsia thus has not established its own authority, but rather has subordinated its authority to that of the larger world system into which it hopes to fit its country. To find the new investors and new markets, to have debt forgiven and new aid provided, the new political leaders of post-communism must convince the international community of their competence. The intelligentsia's new task thus is different from their old aim. Formerly, dependent on their own and their country's resources, they designed and executed a politics suitable to social and systemic transformation. In the future, they no longer establish the aim or the design. Rather, they must now adapt their system to a larger system constructed by others, if they are to win the resources controlled by those outside Eastern Europe.

Nevertheless, I argue against this being the end of the story, which a return to "normalcy" would suggest for an essay on Soviet-type societies. The alternativity of Eastern Europe's futures is still too great to believe that markets will bring properity and democracy, and that the intelligentsia will become good professionals and give up their aspirations for a leading role in the making of Eastern European society.

\section{The alternative futures of the post communist system}

The future of Eastern Europe depends, I should like to argue, on four analytically distinct but related conditions: 1 ) the restoration of a class project for the intelligentsia; 2) the militance of labor; 3) the degree to which exclusive nationalist politics becomes a significant social force; and 4) a society's integration into Europe, not only economically, but politically and socially. In this final section, I focus my remarks on Poland, given that its alternativity is most highly developed.

Although actually existing communism was, as I argued above, antagonistic to the interests of the intelligentsia and especially its ideology of the autonomous intellectual, I still believe that it could have become the class project of the intelligentsia. Instead, in opposition to the Soviettype system, the restoration of civil society became the new project, universal in its claims, but certainly articulated most forcefully by intellectuals. Although it was the articulation of a democratic civil society, the intelligentsia could claim to be its leading force, but once that civil 
society was marketized, as it was over the 1980 s, the intelligentsia could not remain its motor. The entrepreneur and private capital became the new agent of social transformation. This was apparent already before 1989 , but has certainly become obvious in the ideology of the post-communist regime. The material interests of the old communist-made intelligentsia cannot be satisfied with the new system. The old system produced too many engineers and probably too many humanists and historians and writers for the new system to absorb. It produced too many old-style managers. It did not produce the kind of professional needed today. A whole new expertise is required for the new capitalist system in statu nascendi and only a small portion of the old intelligentsia will find a place.

We have not seen any new ideology up to defending the intelligentsia (or the rest of society for that matter) from the market-based civil society. This is based not only on a lack of imagination, but also more fundamentally on a lack of resources to do it. Most East Europeans know where the resources are in the world system today, and a desperate move to get a share of that Western aid is the main concern for most. But I think it will be only a matter of time before a significant portion of the old intelligentsia recognizes that the emergent system can afford only a small portion of their class, even in transformed roles. There will be temptation then to develop a new project that will implicitly claim more for a wider number of their lot. What that project will be depends on a variety of other conditions, the most important of which will probably be the militance of labor, which actually existing Solidarity will do little to foster.

The contest between Tadeusz Mazowiecki and Lech Watesa for the presidency of Poland, ${ }^{109}$ begun much before the official campaign, illustrates the potential chasm between any East European government and labor. Watessa positioned himself, while Mazowiecki was Prime Minister, as the common Pole, critical of those leftist and not entirely Polish eggheads in Warsaw. ${ }^{10}$ But even while positioning himself as the worker, Watęsa would not encourage or even defend strikes, given how that would resonate in the international financial community. An essential part of the reform program was the need to enforce wage discipline. Thus, no matter who comes to power, if they wish western aid, which the search for debt forgiveness was, extraordinary resistance to strikes is essential. The danger, of course, is that further labor militance could move the state to a more authoritarian stand. 
The growing number of strikes and work stoppages by industrial and transport workers has not been led by Solidarity activists therefore, and if so, certainly not with the blessing of the national organization. In contrast, these mobilizations are led by the post-PZPR union of Alfred Miodowicz, and by various Solidarity splinter groups including one led by Marian Jurczyk called Solidarity ' 80 , and one more recently led by the inspiration of the summer 1980 Gdańsk shipyard strike, Anna Walentynowicz. Perhaps even more dangerous are the protests and road blockades led by Poland's farmers legitimately fearful of what further costs of market transition will bring onto them.

Conditions for the rise of anti-market movements in Hungary rather than Poland are advantaged by two factors. First, the leftist tradition is in a slightly stronger position. Indeed, while in the spring of 1990 the Polish post-communist left won less than $1 \%$ of seats nationwide in local elections, the Hungarian left won nearly $10 \%$ in its national contest. Second, and far more important, the old Hungarian trade union apparatus does not have the problem of an "independent" and "patriotic" union movement with which to compete. Solidarity activists today are much more sympathetic to the governmental program than are Miodowicz's activists, and thus are not only refraining from mobilizing strikes, but actively discouraging them. Nevertheless, Hungary's poorer record in workers' organization and militance suggests that Hungary's popular classes may take the same road to survival that they have in the past: working in the second economy even harder than they have in the past, ${ }^{111}$ and Poland's workers may take their old road, but this time in post-PZPR unions or Solidarity splinter groups.

To this point, few from the center of Poland's intelligentsia have moved to embrace these expressions of resistance to the new policies. But given the intensity of conflict at the center, it seems quite likely that some kind of new elite organic intellectuals will emerge from the fray, join the local intellectuals and popular classes, to articulate a new vision. But what kind? One likely and readily available ideology is a nationalist one.

As foreign capital and wealthy foreigners enter the East European lifeworlds in ever greater numbers, the basis for a xenophobic and nativist reaction is laid. Whether or not that passion is kindled depends on other factors, the combination of which is again probably greater in Poland. 
First, the ruling Party controls nationalist politics better in Hungary than in Poland. The Hungarian Democratic Forum is much better situated than Solidarity to contain xenophobic expressions, especially as Poland's major and fundamentalist nationalist movements come from outside of Poland's main Solidarity camp, with Leszek Moczulski's Confederation for an Independent Poland and Marek Jurek's Christian Nationalist Union as examples. So, to take the turf from these outside groups, Solidarity's own nationalist efforts must become more explicit. The Hungarian Democratic Forum need not be so aggressive in proving its patriotic roots.

Walęsa main intellectual supporters, Jaroslaw and Lech Kaczyński, emerged from relative obscurity in Solidarity's illegal days to become the leading force in a new party most clearly aiming to consolidate nationalist claims. During the founding meeting of this Christian Democratic Party, J. Kaczyński said that theirs was like any other European Christian Democratic Party, except insofar as there was no need for such radical separations from the Church. The influence of the Catholic Church in national politics is becoming more obvious, especially with nary a major politician expressing much resistance to the Church's drive to restrict or even make abortion illegal. The prominence of this national religious institution becomes yet another force moving Poland's politics to authoritarian nationalism. With the Catholic institutional structure, and more importantly, in its informal influence, a revival of Polish authoritarianism may thus have an added impetus.

Finally, because Poland's political culture has not abandoned the vision of the great Polish state and still considers the interwar dictator General Pilsudski with unusual reverence, military authoritarianism remains available in the toolkit of Polish nationalism to a degree much unlike Hungary. In summary, should economic transition in Poland produce too much resistance, an iron fist may not prove too alien a strategy.

A renewed class project for the declassed East European intelligentsia could then emerge alongside this new strong state. It could be based on the rebuilding of state administration with non-communist cadre. It would likely involve support for, on the one hand, a mixed economy that could subsidize a public sector where Poland's surplus intelligentsia and workers could still get jobs and, on the other, an educational system that privileges the arts and humanities in the way the old system did. Unlike the old system, small-scale market activity would likely be 
permissible and restraints on civil liberties less formally developed. Gouldner writes that intellectuals are at the center of such nationalist movements throughout the world, but "after that phase is secured," it tends to become internationalist. ${ }^{112}$ Certainly the establishment of an independent state was described by most East Europeans as the culmination of the nationalist project, but given the harshness of economic transition and the descent of the "golden curtain" to replace the iron one, nationalism is likely not a project easily completed. An alternative class project for the East Central European intelligentsia might thus be a revisited nationalism along the lines of the inter-war third road strategy. While this may not be dangerous in Hungary, given the decline of militant nationalism, Poland's conditions and legacy might lead to a less benign project.

Nevertheless, in contrast to inter-war Eastern Europe, East European's new democracies have another condition that militates against nationalist dictatorship in favor of a new international democracy, and one that might become an alternative class project of the intelligentsia.

Had the Mazowiecki government remained in power, I believe that the European identity the democratic intelligentsia worked so hard to cultivate in the days of dissidence would have lost out to the more chauvinistic nationalism that finds in the introduction of foreign capital onto Polish soil confirmation that European identification is a poor substitute for old-style nationalism. Now that the old opposition intelligentsia is back in the opposition, the chances for an alternative and more democratic critique of transition will emerge. This is already apparent in the incipient alliance between the Mazowiecki supporters in Ruch Obywatelski - Alternatywa Demokratyczna, (the Citizen's Movement - Democratic Alternative) and the new group called Solidarność Pracy, or Solidarity of Labor. This alliance might be positioned best to make the crucial connection between workers' defense and Poland's European identity.

To the extent Eastern Europe can rejoin Europe not just on the basis of market or heritage but also on the basis of political ties, the democracy associated with Solidarity of 1980-81 has a better chance of survival. Membership in the European Community can give workers access to a political institution that might give them greater leverage that their own peripheral or semi-peripheral state simply cannot wield in the face of capital's mobility. It could also give them possibilities for jobs that labor migration within the Community would allow. More relevant here, it can reflect a class project of the intelligentsia. 
Zygmunt Bauman argues, ${ }^{113}$ correctly in my view, that the rationalizing intrusive state of modernity creates the space for modern intellectuals by inviting them to provide a culture that legitimates that state's intervention into new spheres of social life. But once state and culture are so constructed, the general intellectual recedes in importance, and might retreat either to a relatively privileged life of autonomy (the independent intellectual), become the interpreter for cultures not represented by the logic of state power (the organic intellectual), or become a servant of bureaucratic power (a professional or technocrat). The European Community, the construction of a new administrative level above states, offers the next great opportunity for the intellectuals' claim to power. It provides a new site for intellectuals' employment, in the administrative and regulatory commissions that become available. But perhaps even more dramatically, it gives intellectuals a new kind of power in the opportunity to legislate a new community of nations and individuals. I believe too that this is probably the intelligentsia class project that will most facilitate the retention, or expansion, of democracy, but an elaboration of this argument will have to be made in another article.

In conclusion, it appears that the Soviet-type system's emancipatory alternative of civil society depends not only on East European identification with the European heritage, but also on its political integration into the European Community. Not only would the East benefit from the West's wealth, but both could benefit from the common purpose that might be constructed in their collaboration. Simply, European political integration might give to the civil societies of Eastern Europe new potential allies that make democracy, and not only capitalism, a greater certainty. The European Community may then be the best political ambition for Gouldner's "flawed universal class" in Eastern Europe.

\section{Notes}

1. I am indebted to the Working Group in Social Theory at the Center for Psychosocial Studies in Chicago for discussions which have contributed significantly to the construction of this article. Thanks are also due Marty Whyte, Roman Szporluk, Jennifer Sell, Ákos Róna-Tas, David Ost, David McQuaid, Ming-cheng Lo, Krzysztof Jasiewicz, Geoff Eley, and Craig Calhoun for comments on previous versions of this text and for general discussions that have helped frame this article's arguments. I am especially appreciative of the comments from Theory and Society's reviewers and Editors, which have helped me to sharpen the article considerably. 
2. "Intellectual" and "intelligentsia" in social scientific discourse have meant many different things. In all cases, identification as intellectual or intelligentsia involves the attribution of some special quality of knowledge to actors. Controversy comes in the definiton of the quality of that distinctive knowledge. To be awarded the distinction, the actor must be able to demonstrate in some generally accessible fashion the superiority of their knowledge, rather than just their special competence. To do that, knowledge is typically based on cultural knowledge, rather than technical knowledge per se, presumably because each field of action has its own expertise while the intelligentsia's superiority rests on the generally superior quality of its knowledge. Hence, when speaking of intellectuals or intelligentsia, "refinement" rather than technial expertise typically comes to mind. See Zygmunt Bauman's "Legislators and Interpreters: Culture as Ideology of Intellectuals," in Hans Haferkamp, editor, Social Structure and Culture (Berlin/New York: Walter de ter, 1989), 331-332. Even when the technocrats are considered part of the more general class of intellectuals, as Alvin Gouldner in The Future of Intellectuals and the Rise of the New Class (Seabury Press, 1979) does, their mark as intellectuals comes in their culture of critical discourse. Bearing then in mind that attribution of intellectual or intelligentsia status comes in the acknowledgment of a distinctive knowledge that is recognizable by an educated lay public rather than only by a speciality, I consider seven variations on this theme below, to clarify how I use the term in this article. There are two very broad general categories of intellectual and intelligentsia. When intellectual is considered the subset of the intelligentsia, (1) the former is distinguished from the larger category by creative powers and a capacity for self definition. When the intelligentsia is distinguished from the larger category of intellectuals, (2) they are generally identified by their inclination for teleological reasoning or their distinctive cultural identity. Within these two most general categories, the intelligentsia remains a controversial term in Eastern European discourse. The intelligentsia can refer to (3) a statistical category (as all those with higher educations in Eastern Europe) (e.g., Jan Szczepański, "The Polish Intelligentsia: Past and Present," World Politics 14 (1962): 406-420); (4) a social group with a special ethos of morality and responsibility (as the old Polish intelligentsia claimed to be the moral government of the nation) (see Aleksander Gella, "The Life and Death of the Old Polish Intelligentsia," Slavic Review 30 (1971): 1-27; or (5) a class with particular consciousness or interests, possibly en route to domination, as Jan Wactaw Machajski suggested in the beginning of this century (see Marshall Shatz, Jan Wactaw Machajski: A Radical Critic of the Russian Intelligentsia and Socialism, Pittsburgh: University of Pittsburgh Press, 1989). In this framework, the intelligentsia is distinguished from another kind of intellectual, professionals, whose technical knowhow and occupational distinction mark their distinctive identification, not their teleological reasoning or their culture. For the best recent statement on this, see Ivan Szelényi, "The Intelligentsia in the Class Structure of State-Socialist Societies," in M. Burawoy and T. Skocpol, editors, Marxist Inquiries (Chicago: University of Chicago Press, 1982), 287-326. This more specific approach is the one I prefer for understanding the place of the highly educated in the power relations of the Soviet-type system. The intellectual as category also can become an object of controversy, for it can become (6) a category of relative exclusiveness based on some special responsibility, experience or achievement, as Stanisław Barańczak suggests in "The Polish Intellectual," Salmagundi 70-71 (1986-87): 217-228, or it can refer to (7) a capacity of all men and women that is exaggerated or repressed under various 
social circumstances as Antonio Gramsci ("The Intellectuals," in Selections from the Prison Notebooks, 5-23 (London: Lawrence and Wishart, 1971)) or more recently Alan Montefiore ("The Political Responsibility of Intellectuals," 201228 in Ian Maclean, Alan Montefiore, and Peter Winch, editors, The Political Responsibility of Intellectuals (Cambridge: Cambridge University Press, 1990) emphasize. This final approach is more useful for understanding the transformative capacities of actors in Soviet-type societies, rather than the structural determinations of their conditions. For an elaboration of this point, see my essay, "The Constitution of Critical Intellectuals: Polish Physicians, Peace Activists and Democratic Civil Society" Studies in Comparative Communism 23.3/4 (1990): 281-303. English language complicates exposition because the "intelligentsia" has no singular noun associated exclusively with it, as Polish does in its distinction between inteligent and intelektualista. Hence, when I use the term "intellectuals" it refers to the larger category of all those with special claims to knowledge, as suggested in the second general categoory.

3. Yugoslavia's transition is also internally driven, but it is less useful for anticipating the future of the rest of Eastern Europe for several reasons. First, it does not have to transform its political and economic systems so completely and so simultaneously as the rest of Eastern Europe. It already challenged, ideologically and practically, the Stalinist economic system and its measure of central planning decades ago. Secondly, while its measure of political and national decentralization makes it a more appropriate model for the USSR than for the other more centralized states of Eastern Europe, as Bogdan Denitch in Limits and Possibilities: The Crisis of Yugoslav Socialism and State Socialist Systems (University of Minnesota, 1990) argues, the centrality of ethnic/national conflict in the South Slav state means that political economic questions can be put off the public agenda, a matter less easily accomplished in the rest of Eastern Europe, even in the federal state of Czechoslovakia. And finally, the project to create civil society in Yugoslavia does not have the convenient association of communism and imperial domination, especially as Slovenian and Croatian communists come to take the struggle for their sovereignty seriously.

4. See Michael D. Kennedy, "The Lessons of Eastern Europe for Critical Intellectuals," in Charles Lemert, editor, Intellectuals and Politics: Social Theory in a Changing World (Beverley Hills: Sage Press, 1991).

5. See Chapter 6 of Michael D. Kennedy, Professionals, Power and Solidarity in Poland: A Critical Sociology of Soviet-Type Society (Cambridge: Cambridge University Press, 1991).

6. See György Konrád and Iván Szelényi, The Intellectuals on the Road to Class Power (New York: Harcourt, Brace, Jovanovich, 1979); Szelényi, 1982; Iván Szelényi, "The Prospects and Limits of the East European New Class Project," Politics and Society 15: 103-144.

7. See Kennedy, "The Constitution of Critical Intellectuals."

8. Rudolph Bahro, The Alternative in Eastern Europe (London: New Left Books, 1978).

9. Jeffrey Goldfarb, On Cultural Freedom (Chicago: University of Chicago, 1982) mainly discusses artists and writers in this vein, but the argument is easily extended to other creative intellectuals.

10. See Kennedy, "East European Lessons ...," 1991.

11. As usual, Yugoslavia and Albania are exceptions.

12. E.g., Leszek Moczulski, Rewolucja bez Rewolucji (Warsaw: Wydawnictwo Polskie, 1979). 
13. In Josef Gorlice, 148, "Introduction to the Hungarian Democratic Opposition," Berkeley Journal of Sociology 30 (1986): 117-165.

14. János Kis, "Hungarian Society and Hungarian Minorities Abroad," Beszélo 7 (1983), reprinted in Politics in Hungary: For a Democratic Alternative (New York: Columbia University Press, 1989), 197-208.

15. Milan Kundera, interviewed by Alain Finkielkraut in Cross Currents 1: 15-29 (1982); Jeno Szücs, "Three Historical Regions of Europe," in John Keane, editor, Civil Society and the State (London: Verso, 1988), 291-332.

16. Adam Michnik, "Notes on the Revolution," The New York Times Magazine (11 March 1990): 38-45.

17. Szczepański, 1962.

18. Maria Hirszowicz, The Bureaucratic Leviathan (New York: New York University Press, 1980).

19. E.g., Andrew Arato, "Critical Sociology and Authoritarian State Socialism," in John B. Thompson and David Held, editors, Habermas: Critical Debates, 196-218 (Cambridge: MIT Press, 1982).

20. See Chapter 7 in Kennedy, Professionals, Power and Solidarity.

21. See Michael D. Kennedy and Maurice D. Simon, "Church and Nation in Socialist Poland," in Peter H. Merkl and Ninian Smart, editors, Religion and Nationalism in the Modern World (New York: New York University Press, 1983).

22. Adam Michnik, Kościót, Lewica, Dialog (Paris: Kultura, 1977).

23. Adam Michnik, "The New Evolutionism," in Letters from Prison and Other Essays (Berkeley: University of California Press, 1976/1985), 135-148.

24. Neopositivism was the strategy of Stanislaw Stomma and others around the Catholic group Znak who believed that participation in existing institutions, even if one rejects decisively their lasting value, is the best means for assuring progressive change.

25. Michnik, 1976, 142.

26. Michnik, 1976, 148.

27. Of the 37 people mentioned by Jan Józef Lipski in KOR: Workers Defense Committee in Poland (Berkeley: University of California Press, 1985), 9 were men and women of letters and 6 were historians.

28. Lipski, 1985.

29. Roman Laba, The Roots of Solidarity (Princeton: Princeton University Press, 1991).

30. Andrew Arato, "Civil Society Against the State," Telos 50 (1981): 19-47.

31. Jadwiga Staniszkis, "On Some Contradictions of Socialist Society: The Case of Poland," Soviet Studies 31 (1979): 167-187.

32. Marian Kostecki and Krzysztof Mreła, "Collective Solidarity in Poland's Powdered Society," The Insurgent Sociologist 12 (1984): 131-142.

33. Jacek Kurczewski ("Power and Wisdom: The Expert as Mediating Figure in Contemporary Polish History" 77-100 in Maclean et al., editors, The Political Responsibility of Intellectuals makes an important point: that intellectuals realized their influence in two ways: as experts and as elected union leaders, the most evocative example being that the coauthors of the 1966 "Open Letter to the Party," Jacek Kuron and Karol Modzelewski, both found themselves prominent in the movement, but Kuroń as expert/advisor, and Modzelewski as union leader.

34. Laba, 1991.

35. See Chapter 3 in Kennedy, Professionals, Power and Solidarity.

36. Alain Touraine with F. Dubet, M. Wieviorka, and J. Strzelecki, Solidarity: The 
Analysis of A Social Movement (Cambridge: Cambridge University Press, 1983).

37. Kennedy, Professionals, Power and Solidarity.

38. Janina Frentzel-Zagórska and Krzysztof Zagórski, "East European Intellectuals on the Road of Dissent," Politics and Society 17 (1989): 89-113. By imputed class interests I mean a more etic approach in which the ascription of identity to social actors is based on their location in a system of relations of production and distribution identified by the analyst; by cultural self-definition I mean a more emic approach in which the self understandings of actors is privileged in the identification of the meanings of group action.

39. János Kis, "The Present Crisis and its Origins," Századvég 3-4 (1988), reprinted in Politics in Hungary: For A Democratic Alternative (New York: Columbia University Press, 1989), 85-96, esp. 95.

40. See Michael D. Kennedy, "Hermeneutics, Structuralism and the Sociology of Social Transformation in Soviet-Type Society," Current Perspectives in Social Theory 8 (1987): 47-76.

41. E.g., Moczulski, 1979.

42. Pierre Kende, "Functions and Prospects of the Democratic Opposition in Hungary," in A. Smolar and P. Kende, editors, The Role of Opposition, Study Number 17-18 (Research Project Crises in Soviet-Type Systems, Munich, 1989), 64-66.

43. Kis, $1988,95$.

44. Kende, $1989,68$.

45. They include Ágnes Heller, Ferene Fehér, György and Mária Márkus, István Kemény, Iván Szelényi, and Mihály Vajda. Vajda returned to Hungary shortly thereafter, however.

46. Gorlice, 1986, 119, 128.

47. Vajda in Gorlice, 1986, 151.

48. Szelényi, 1986-87.

49. Iván Szelényi, "Intellectuals, Knowledge and Power," presentation at the Annual Meeting of the American Sociological Association, 1989. One of the reviewers of my article suggested that in this sense Gouldner was more right than Szelényi: that intellectuals came to power with their own culture of critical discourse rather than by merging with rational redistributive power. Certainly this is true, as the intellectuals are aiming to undermine the old "planned" system and replace it with one resting on markets. But I am not sure that this culture of critical discourse will remain the dominant position of the intelligentsia in post-communist transition, as the conclusion shall argue. CCD may give way to nationalist ideology and state remaking.

50. János Kis, "The End and the Beginning," Beszélő 19 (1987), reprinted in Politics in Hungary: For A Democratic Alternative (New York: Columbia University Press, 1989), 7-22, esp. 9, 22.

51. János Kis, "Can 1956 Be Forgotten?" Égtájak Között 3 (1986), reprinted in Politics in Hungary: For A Democratic Alternative (New York: Columbia University Press, 1989), 23-30, esp. 26-27.

52. János Kis, "After the Fall Session of the National Assembly," Beszélo 21 (1987), reprinted in Politics in Hungary: For A Democratic Alternative (New York: Columbia University Press, 1989), 153-174, esp. 13.

53. János Kis, "The 1956-57 Restoration in a Thirty Years Perspective," in János Kis et al., Magyaroszág 1956 (Budapest: AB Független Kiadó, 1986), reprinted in Politics in Hungary: For A Democratic Alternative (New York: Columbia University Press, 1989), 31-84, esp. 75. 
54. Ibid., 47.

55. Ibid., 75 .

56. Kis, "Can 1956 be Forgotten?," 28.

57. Kis, "The 1956-57 Restoration," 81.

58. Ferenc Fehér and Ágnes Heller, Hungary 1956 Revisited (London: Allen and Unwin, 1983).

59. Kende, 55-56.

60. Kende, 56-57.

61. Kis, "After the Fall Session."

62. Ibid., $169-170$.

63. There is limited information about workers' militance, although there have been some strikes and other independent actions taken by industrial workers. These actions have rarely proceeded beyond immediate locales given the efforts by enterprise managers and political authorities to appease demands and thus contain their opposition. Catholic grassroots communities also have been formed, but even less has been written about them.

64. This account of actors draws on several sources: Kende; Nigel Swain, "Hungary's Socialist Project in Crisis," New Left Review 176 (1989): 3-31; László Bruszt, "The Roundtable Negotiations in Hungary and Poland: A Comparison" (Lecture at The University of Michigan, 10 November 1989); see also the related article published subsequently: "1989: The Negotiated Revolution in Hungary" Social Research 57.2 (1990): 365-388; George Schopflin, Lecture on Hungary at the University of Michigan, 6 November 1989; László Urbán, "Hungary in Transition: The Emergence of Opposition Politics," Telos 79 (1989): 108-118; József Szajer, Interview, 15 February 1989; Mitchell Cohen, "The Withering Away of the Communist State," Dissent, Fall (1989): 455-461.

65. Schopflin.

66. György Konrád, Antipolitics (New York: Harcourt, Brace, Jovanovich, 1984), 54.

67. József Szajer, "Law and Political Change in Hungary: The Case of FIDESZ," Lecture at The Unversity of Michigan, 15 February 1989.

68. Szajer, Interview.

69. Karl Marx, "On the Jewish Question," in Robert Tucker, editor, The Marx-Engels Reader (New York: Norton, 1843/1978).

70. Bruszt; Janet Fleischman, "New Independent Youth and Trade Union Organizations: An Emerging Civil Society? Across Frontiers, Winter/Spring (1989): 28.

71. Some blue-collar unions formed, as the transport workers and ambulance workers. Swain anticipates growth in independent blue-collar unions.

72. Urbán.

73. Bruszt.

74. Tamás Bauer, "Hungarian Economic Reform in East European Perspective," Eastern European Politics and Societies 2.3 (1988): 418-432, esp. 425-426.

75. Gorlice.

76. Swain, 17.

77. Urbán.

78. Schopflin.

79. The Opposition Round Table included two populist groups, Hungarian Democratic Forum and the Bajcsy-Zsilinszky Fraternal Society, several liberal urban groups, FIDESZ, the Alliance of Free Democrats and the League of Democratic Trade Unions, and three "nostalgia" parties, the Social Democrats, the Hungarian People's Party, and the Smallholders Party (Swain). 
80. In October 1989 Pozsgay attempted to take over the Party, but he discovered that the reformist wing had only $2 / 5$ of the votes. It was instead dissolved, with the reformists constituting the Hungarian Socialist Party (Schopflin).

81. Bruszt.

82. In his comment on Schopflin's talk, Ákos Róna-Tas suggested this paradox: a weak Hungarian opposition could establish an easy victory over communists, while a strong Polish opposition produced a bitter struggle. Schopflin responded that this was because the recurrent defeats of the Polish party hardened it, while the Hungarian authorities were soft. They avoided imprisoning the opposition and could allow the transition because there were no strong divisions between authorities and society. This answer, in fact, understates the significance of class, as I attempt to establish in the conclusion.

83. In this section, I rely most heavily on Aleksander Smolar's detailed discussion of the Polish opposition, in "The Polish Opposition," in A. Smolar and P. Kende, The Role of Opposition, Study Number 17-18 (Research Project Crisis in Soviet-Type Systems, Munich, 1989).

84. David S. Mason, "Poland's New Trade Unions," Soviet Studies 39 (1987): 489-508, esp. 502.

85. Smolar, 19.

86. Smolar, 14.

87. Andrzej Walicki, "Liberalism in Poland," Critical Review 2 (1988): 8-38.

88. Smolar.

89. Smolar.

90. David Ost, "The Transformation of Solidarity and the Future of Central Europe," Telos 79 (1989): 69-94, esp. 76.

91. Walicki; Ost; Smolar.

92. Adam Michnik, Press Conference at The University of Michigan, 27 November 1989; Janusz Rejkowski, "The Roundtable Negotiations from an Actor's Perspective: Psychological Aspects of the Transformation of Political Systems," Lecture at The University of Michigan, 17 October 1989.

93. See Rudolf L. Tokes, "Hungary's New Political Elites: Adaptation and Change, 1989-90" Problems of Communism, Nov.-Dec. (1990): 44-65, especially page 57.

94. See my discussion of János Kis in notes 50-54 above.

95. The best example of this is Zbigniew Brzeziński's approach to the end of communism. See for example, The Grand Failure: The Birth and Death of Communism in the Twentieth Century.

96. Touraine et al.

97. Timothy Garton Ash, "Revolution in Hungary and Poland," New York Review of Books 36.13 (17 August 1989): 9-15.

98. I adopt the Polish convention here of describing groups that formerly had ties to the Polish United Workers Party (PZPR) that nevertheless have new or different names as "post-PZPR" simply to emphasize their ancestries.

99. Alfred Miodowicz, "Pozostajemy Sobạ" Polityka 48 (2 December 1989): 10.

100. Ash, 1989: 10.

101. Timothy Garton Ash. The Magic Lantern: The Revolution of '89 Witnessed in Warsaw, Budapest, Berlin and Prague (New York: Random House, 1990), 18-26.

102. Marek Henzler, "Wygrali w Prawyborach," Politika 21 (27 May 1989): 3.

103. Ákos Róna-Tas, Personal Communication, 10 June 1990; for a more detailed breakdown of occupations, see Tokes, 60 . This surge of intelligentsia representa- 
tion in parliaments is one of the more powerfully consistent outcomes of postcommunist movements. See also David Lane, Soviet Society under Perestroika, 66.

104. Jerzy Baczyński, "Ile Będzie Solidarność?" Polityka, \#35 (2 December 1989): 1.

105. Ost, 84.

106. See Iván Szelényi, Socialist Entrepreneurs: Embourgeoisment in Rural Hungary (Madison: University of Wisconsin Press, 1988); David Stark, "Coexisting Organizational Forms in Hungary's Emerging Mixed Economy," in Victor Nee and David Stark, editors, Remaking the Economic Institutions of China and Eastern Europe (Stanford: Stanford University Press, 1989); Ákos Róna-Tas, The Second Economy in Hungary: The Social Origins of the End of State Socialism, unpublished Ph.D. dissertation, The University of Michigan, 1990.

107. See János Kornai, "Socialist Transformation and Privatization: Shifting from a Socialist System" Eastern European Politics and Societies 4.2 (1990): 255-304.

108. See Adam Fallenbuchl and Zbigniew Fallenbuchl, "Privatization and Marketization in Poland" Studies in Comparative Communism 23.3/4 (1990): 349-354.

109. The surprisingly strong performance by outsider Stan Tymiński reflects the considerable potential for new actors and ideologies mobilizing support against an increasingly isolated and elitist Solidarity. I cannot comment in this article on the pecularities of this campaign.

110. By leftist, the centrists understood those who continued to honor the $1989 \mathrm{com}-$ promise agreement with communists, rather than booting them out as the rest of Eastern Europe had done. By "not entirely Polish," right-wing nationalists indicted Mazowiecki's team for having people with Jewish ancestry, going so far as to imply that Mazowiecki himself had such lineage. There is also a contest in Poland over what should be the appropriate urban center for leading national renewal. Unlike Hungary, where Budapest is self evident, Warsaw is only the capital of the country; Kraków was the country's capital long ago and a rival intellectual center, and Gdańsk is the home of Solidarity. "Egghead" has international resonance.

111. See Róna-Tas, The Second Economy in Hungary.

112. Alvin Gouldner, 83, The Future of Intellectuals.

113. In Legislators and Interpreters: On Modernity, Postmodernity and the Intellectuals (Oxford: Polity Press, 1987) in addition to his essay "Legislators and Interpreters" cited above. 